\title{
Методология, методика, опыт работ по сохранению и приспособлению для современного использования парка Усадьбы Михалково. Часть 2
}

\author{
Е.Л.Беляева, ИГБИ, Москва \\ И.А.Маркина, Москва \\ Р.Г.Могинов, Москва
}

\section{0 статусе, режимах и границах объекта культурного наследия}

Благодаря ансамблю, созданному В.И. Баженовым в конце XVIII столетия, усадьба «Михалково» была одной из красивейших в окружении Москвы. Как мы убедились, несмотря на исторические трансформации, она сохранила многое из своего облика и является замечательным примером для изучения особенностей парков этого периода.

Статус памятника истории и культуры регионального значения - произведения садово-паркового искусства, усадьба получила в 1979 году, однако «Росохранкультурой» он был утверждён только в 2011-ом. Границы памятника утверждены Постановлением Правительства Москвы № 790 от 17.08.1993 г. «0б утверждении границ памятников архитектуры и садово-паркового искусства усадеб "Грачевка" и "Михалково" и их зон охраны».

Для рассматриваемого объекта культурного наследия (ОКН) в разные годы было выполнено несколько научнореставрационных исследований и проектных работ с обоснованием мероприятий по реставрации и приспособлению к современному использованию. Работы упоминаются в первой части статьи ${ }^{1}$. Однако ни в одной из них не был поставлен вопрос корректировки границ ОКН и охранных зон. На наш взгляд, эта проблема является важной вдвойне в связи с современным развитием территорий в окружении объекта. Градостроительную ситуацию и перспективы иллюстрируют материалы НИИПИ Генплана Москвы (рис. 1).

При натурных обследованиях парка, анализе современных и архивных планов видно, что утверждённые границы ОКН недостаточно обоснованы с историко-культурной и градостроительной точки зрения, не соответствуют сложившемуся землепользованию района, плотно застроенного в 1960-1970 годы. Они далеко выходят за ограждения парка и/или проходят по участкам сторонних пользователей. Как сложившееся функционально-планировочное образование парк сегодня тоже границ не имеет.

Границы ОКН регионального значения, утверждённые Постановлением Правительства Москвы проходят вдоль улиц Михалковская, Онежская и Нарвская, красных линий Кронштадского бульвара и по внутриквартальным проездам жилой застройки. Местами они далеко выходят за огражде-

${ }^{1}$ Первая часть статьи «Методология, методика, опыт работ по сохранению и приспособлению для современного использования парка усадьбы Михалково опубликована в № 1 журнала «Academia. Архитектура и строительство» за 2020 год. ния смежных землепользователей - участков общественной и жилой застройки, а также на земли улично-дорожной сети.

Площадь объекта культурного наследия регионально значения - произведения садово-паркового искусства «Усадьба Михалково» в утверждённых границах составляет 50,6 га. Площадь «ядра усадьбы», имеющего статус объекта федерального значения, - 8,3 га. Ядро усадьбы включает архитектурный ансамбль парадного двора конца XVIII века (архитектор В.И. Баженов) и регулярный парк с копаными прудами.

При проектировании реставрации и приспособления парка к современному использованию в 2014-2017 годы вопросами корректировки границ и межевания, к сожалению, никто не занимался. Сосредоточились исключительно на благоустройстве. Кадастровые границы территории ОКН регионального значения - произведения садово-паркового искусства «Усадьба Михалково», тогда тоже не были сформированы из-за многочисленных претензий к ним со стороны сторонних и смежных землепользователей. До последнего времени парк не имел «балансодержателя», дирекции, охраны. Эксплуатацию и текущий ремонт территории много лет вели коммунальные службы района, прудов - Мосводосток.

Пример Михалкова показывает, насколько сложным может быть комплекс проблем сохранения исторических парков, расположенных на территории современных городов, особенно в окружении плотной застройки. В Москве это - Царицыно, Грачёвка, Фили, Кусково, Кузьминки и др. На территории таких парков, как правило, одновременно действует несколько видов линий градостроительного регулирования - от пяти до восьми. Например, в Михалково - границы территории ОКН, границы ОКН, границы территории ПК, границы водоохранных зон, в том числе - береговой и прибрежной, границы зоны охраняемого ландшафта, границы охраняемого культурного слоя и др. В усадьбе и парке Фили-Кунцево действуют статус 00ПТ (ПИП «Москворецкий») и статус памятника археологии.

Несоблюдение режимов использования территории, имеющей статус объекта культурного наследия, может нарушить одновременно Земельный, Градостроительный и Водный кодексы. В парке Михалкова, например, нарушается статус территории Природного комплекса Москвы (ПК). Таким образом, на примере рассматриваемого парка видно, насколько острыми для методологии парковой реставрации являются проблемы научно-обоснованных границ, статуса, соблюдения режимов использования территории.

Для «Михалково» и многих других исторических парков, расположенных в городских условиях, где объекты и терри- 


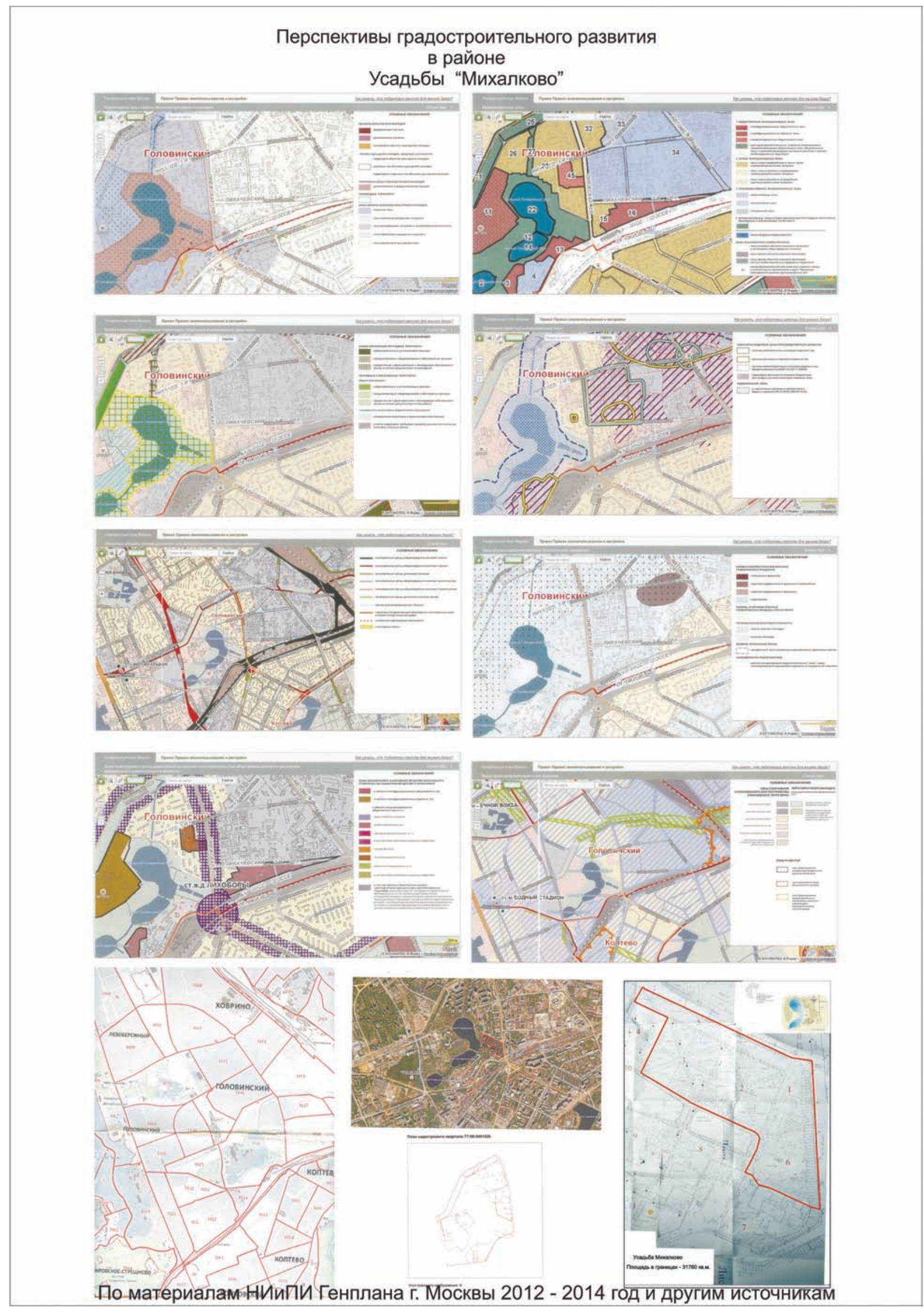

Pис. 1. Местоположение, границы, градостроительное окружение объекта культурного наследия «Усадьба Михалково» 
тории, входящие в «предмет охраны», используются не по назначению, актуальной задачей является вывод «сторонних пользователей». Допустимо их перепрофилирование в соответствии со статусом и режимом объекта культурного наследия.

В Михалкове статус ОКН имеют реставрируемые флигели парадного двора, в которых много лет размещаются административно-технические помещения $3 \mathrm{AO}$ «Михалково». Организация много лет занималась реставрацией парадного двора, оформила права собственности и заключила «охранный договор».

Регистрация прав собственности (или аренды) объектов недвижимости с установлением вида использования, не противоречащего статусу и режиму ОКН, наряду с межеванием создаёт предпосылки для упорядочения функционального использования объектов и территорий, оформления охранных обязательств и установки ограждения по границам парка. Это первые, но обязательные шаги к сохранению произведения садово-паркового искусства, которые должны рассматриваться как предпроектный этап парковой реставрации

В парке усадьбы Михалково и в аналогичных случаях недопустимо необоснованное включение в состав ОКН территорий, прилегающих к парку, расположенных вне его фактических границ, не имеющих с парком функциональных и визуальных связей. На рассматриваемом объекте при натурных обследованиях, анализе архивных материалов мы не нашли веских оснований для выхода границ ОКН на прилегающие территории, где отсутствовали особенности, составляющие «предмет охраны» и «выявленные объекты».

Как показал визуально-ландшафтный анализ, территории, расположенные за ограждением парка или ограждениями «смежных землепользователей», не влияли на восприятие ландшафтных особенностей парка.

При соответствующем обосновании границы и режимы использования территории произведения садово-паркового искусства «Усадьба Михалково» целесообразно скорректировать. Исключить застройку прилегающих к парку участков жилого и общественного назначения можно, установив для этих участков статус и режим зоны строгого регулирования застройки и необходимые ограничения П33.

Таким образом, важнейшими требованиями сохранения исторической усадьбы Михалково и пейзажного парка являются корректировка границ ОКН и охранной зоны, регламентов и режимов использования территорий. После этого целесообразно выполнить межевание территории кадастровой зоны квартала МО «Головинский» в границах охранной зоны ОКН.

Парковой реставрации 2017 года, охватывавшей большую часть территории безусловно, должны были предшествовать работы по корректировке границ ОКН, охранной зоны, работы по упорядочению использования объектов и территорий в соответствии с их статусом, кадастровые работы, но они не выполнялись. Это негативно повлияло на качество проекта.
При большой площади работ и значительных затратах реставрация не стала комплексной, не решила основных задач упорядочения границ и современного использования территории парка как единого функционально-пространственного образования. На ряде участков оказались невозможными установка новых ограждений, снос дисгармоничных сооружений и искажающих восприятие парка и не исторических бетонных и металлических ограждений, принадлежащих сторонним и смежным землепользователям.

Перспективные направления в исследовании особенностей и «предмета охраны» пейзажного парка

В первой части статьи мы уже говорили о значении научнообоснованных подходов к сохранению выдающегося произведения садово-паркового искусства «Усадьба Михалково», учёта особенностей, характерных для пейзажных парков конца XVIII столетия. В.А. Горохов в своей книге «Зелёная природа города. Садово-парковое искусство России» [1] именно на примере Михалкова рассматривает характерные приёмы устройства пейзажных парков этого периода. 0 н обращает внимание на то, что отличительной особенностью создания пейзажных парков, характерных для творчества В.И. Баженова и его последователей, является то, что дворцово-парковые ансамбли ими создавались не по принципу «парк при дворце», а по принципу «дворец при парке». Мы видим, что это в полной мере относится и к усадебным паркам. Пример устройства парка Михалкова это полностью подтверждает.

Главной особенностью Михалкова как произведения садово-паркового искусства конца XVIII века, имеющего отношение к творчеству В.И. Баженова, безусловно является главенствующая роль парка. Парадный двор не доминирует в архитектурно-пространственной композиции, а «главный дом» так и вовсе не был построен. Возможно, это объясняется особенностями распространённой в этот период символической архитектуры масонства, и этот вопрос требует дополнительного исследования.

Достоверно известно, что русские сады и парки в конце XVIII века в основном - пейзажные («натуральные сады») [1-7]. Это хорошо видно на примере Михалкова. Часто пейзажные парки включают более ранние, уже существовавшие в усадьбах регулярные парки, водоёмы, лесные массивы и рощицы. Известный паркоустроитель того времени А.Т. Болотов рекомендовал естественные рощицы превращать в «увеселительные лесочки» [8; 9]. В отношении парка как произведения садово-паркового искусства можно говорить именно об авторстве В.И. Баженова, которое в предмете охраны на сегодняшний день обозначено только в отношении ансамбля парадного двора и беседок-ротонд.

Многие «исследователи» Михалкова говорят о том, что пейзажный парк усадьбы практически не сохранился. Действительно, в пейзажном парке не сохранились насаждения того периода, дорожно-тропиночная сеть. Они и не могли сохраниться по прошествии более 250 лет. Но сохранилось 
главное: при всех исторических трансформациях усадьбы и парка очевидна определяющая роль частично преобразованного природного ландшафта и водных поверхностей в данном произведении садово-паркового искусства, их доминирование над ансамблем парадного двора, особая «конструктивная» роль визуальных раскрытий местности, которые были использованы при формировании композиции данного произведения садово-паркового искусства, акцентирование наиболее выразительных элементов рельефа.

Схема усадьбы Михалкова с пейзажным парком, приведённая работе В.А. Горохова [1 и др.], конечно, достаточно условна, возможно, даже не вполне достоверна и не учитывает исторических трансформаций в парке. Зато она хороша как «модель» пространственной организации парка, которая указывает на главное в формировании и восприятии данного произведения садово-паркового искусства, где определяющую роль играют природо-обусловленные факторы.

Модель говорит о важности учёта особенностей рельефа и гидрологических объектов - обширных водных поверхностей, изначально предопределивших выбор местоположения и архитектурно-пространственную композицию рассматриваемого произведения садово-паркового искусства и указывающих на его принадлежность «стилю». Эти «особенности», которые должны войти в «предмет охраны», их детальное описание и привязка к местности должны тщательно изучаться, сохраняться и определять в будущем условия восприятия ансамбля и парка.

Результаты натурных исследований парка и анализ картографических источников подтверждает, что при его создании был использован естественный, уже частично преобразованный ландшафт усадьбы Михалково и что для данного ансамбля существует настоятельная необходимость дополнительного исследования архитектурно-композиционной роли ландшафта в целом, отдельных форм рельефа, конфигурации и параметров гидрологических и гидрогеологических объектов и их фиксации в «предмете охраны».

Самостоятельным направлением изучения особенностей усадьбы Михалково, как произведения садово-паркового искусства является исследование современного восприятия дальних перспектив и панорамных видов на водные поверхности Головинских прудов, на регулярный парк с ансамблем парадного двора и копаными прудами, их фотофиксация и визуально-ландшафтный анализ с классификацией по степени сохранности исторических видов.

При обследовании мы не увидели в Михалкове ни исторической свободной планировки, ни элементов исторических насаждений периода создания парка. Эти особенности действительно утрачены. Но очевидно, что в конце XVIII столетия в Михалкове создавался усадебно-парковый ансамбль, выполненный по канонам того времени в стилистике пейзажного парка и в нём была и свободная планировка, акцентированная постройкой выразительного ансамбля парадного двора с прилегающим регулярным парком, по- садками и парковыми сооружениями (сохранившимися беседками-ротондами), видовыми площадками и лестницами - спусками к воде.

Интересно, что в ряде источников приводится описание усадьбы Михалково, данное английским путешественником Уильямом Куксом, посетившим её в конце XVIII века. В нём говорится, что сад усадьбы устроен в английском вкусе с хорошенькими лужайками, группами деревьев и большим прудом, обсаженным деревьями. Таким образом акцент путешественник сделал именно на пейзажном парке, бывшем в то время был в большой моде, а не на регулярном, а также на большом (Головинском ) пруде, а не на копаных прудах регулярного парка. Англичанина регулярный парк интересовал меньше.

Тем не менее в Михалкове роль регулярного парка с копаными прудами весьма значительна. Вместе с парадным двором регулярный парк формирует «ядро усадьбы», и благодаря этому небольшой архитектурный ансамбль парадного двора получает значительно больший масштаб и значимость, но при этом гармонично входит в свободную ландшафтную композицию большого пейзажного парка.

К сожалению, в «Паспорте...» памятника садово-паркового искусства особенности уникального ландшафта пейзажного парка в описании предмета охраны практически не отражены, несмотря на то, что для этого есть все основания. Хочется остановиться также на других особенностях, установленных при натурном обследовании:

1) размещение ансамбля парадного двора в виде крепости расположенной на возвышенности с направлением главной композиционной оси север-юг и дополнительной - западвосток, с организацией трёх входов и въездов, оформленных попарно башнями и с раскрытием композиции на север в сторону регулярного парка с копанными прудами;

2) главный въезд на территорию парадного двора - южный, со стороны современной Михалковской улицы. Восточные ворота обеспечивали выход в парк и в хозяйственную зону усадьбы, к водопойному пруду, положение которого зафиксировано установкой каменной беседки-ротонды. Западные ворота предназначались для выхода (выезда) пейзажный парк к Головинским прудам. От западных ворот осуществлялась непосредственная функциональная и визуальная связь парадного двора и пейзажного парка с Головинскими прудами;

3) широтная ось композиции ансамбля парадного двора (запад-восток), второстепенная по сравнению с главной осью - север-юг (главный въезд - главная аллея регулярного парка). Пересекая парадный двор, она уходит вглубь пейзажного парка к прудам и далее на запад в окрестности усадьбы. Она важна в общей полицентрической и разнонаправленной (многоосевой) композиции парадного двора, в которой восточные и западные ворота обеспечивают визуально-пространственные связи ансамбля. Через кованые металлические ворота западного въезда парадного двора и с внешней стороны этих ворот существуют важные видовые раскрытия ландшафта, ранее это была панорама Головинских прудов; 
4) несмотря на то, что восприятие пейзажного парка на продолжении широтной оси композиции к берегу пруда искажено дисгармоничным строением - кассой лодочной станции советского периода, а местоположение современной дорожки, ведущей от восточных ворот к пруду, не соответствует историческому, совершенно неоспорима и требует восстановления непосредственная взаимосвязь ансамбля через западные ворота с берегом Головинского пруда. Историческое местоположение дорожки, ведущей от ворот к пруду, хорошо просматривается при натурном осмотре, поскольку оно закреплено аллейными посадками послевоенной реставрации XX века;

5) натурное обследование показывает, что в будущем существует возможность восстановить частично утраченные или искажённые визуальные связи расположенного на возвышенности парадного двора, регулярного и пейзажного парков и дополнительно акцентировать исторические взаимосвязи, в том числе - включённость архитектурного ансамбля и регулярного парка в обширное ландшафтное пространство пейзажного парка. Это может достигаться через формирование запоминающихся панорам и видовых раскрытий ландшафта (туда и обратно) при условии сноса неисторических дисгармоничных сооружений, ограждений, разборки твёрдых (асфальтовых и плиточных) покрытий на территории и вокруг парадного двора.

6) историческое положение моста усадьбы Михалково - приблизительно в створе беседки-ротонды, что видно на архивной карте (см. часть 1, рис. 1). Мост, соединявший берега Большого Головинского пруда, не может быть восстановлен, поскольку место, где он располагался, сегодня самое широкое место акватории. Поскольку пруды усадьбы искусственные, их конфигурация и уровень безусловно могли меняться в зависимости от величины годового стока и сезонных колебаний. Требований к аутентичности береговой линии в исторических пейзажных парках с водоёмами, устроенными запрудами, по-видимому, не стоит придавать большого значения. Важно, что каскад прудов, соединённых каналом, и огромное водное зеркало как основа ландшафтной композиции усадьбы сохраняются и что сегодня берега прудов остаются незастроенными;

7) особенностью, подтверждающей принадлежность парка Михалкова пейзажному стилю, является установка двух каменных беседок-ротонд за границами регулярного парка. Беседки были установлены в конце XVIII века, автором считают В.И. Баженова. Беседка у видовой площадки на правом высоком берегу Большого Головинского пруда расположена на максимальной отметке рельефа недалеко от ансамбля парадного двора и попадает в зоны главных видовых раскрытий ландшафта и панорам с левого берега практически на всём его протяжении, а также со стороны набережной, расположенной на дамбе у входа в Головинский канал;

8) размещение видовой площадки с беседкой-ротондой и лестничного спуска к воде было не случайным, а хорошо продуманным. Это подтверждается визуально ландшафтным анализом в наши дни. Кроме утилитарных целей, беседка, установленная на берегу Головинского пруда, зафиксировала вид в сторону парадного двора из северной удалённой части парка. Это важно, поскольку архитектурные сооружения парадного двора не имели достаточной высоты и беседкаротонда, установленная на высоком правом берегу, визуально указывает на направление положения парадного двора в пространстве парка;

9) утверждённый «предмет охраны» регулярной части парка в основном сохраняется. Сохранились копаные пруды, главная аллея, историческая планировка запрудной части, береговые аллеи, звездообразные аллеи с круглыми площадками, северная часть «огибной» дорожки. Значительная часть сооружений регулярного парка не сохранилась. Утрачен обводнённый канал, водопойный пруд, расположенный недалеко от восточной беседки-ротонды, другие парковые сооружения и хозяйственные постройки, которые видны на исторических планах;

10) анализ состояния архитектурного ансамбля парадного двора, его зданий, сооружений и территорий во взаимосвязи с регулярным парком показывает, что композиционные особенности ядра усадьбы в составе пейзажного парка в основном сохраняются несмотря на временно установленное ограждение, отделяющее парадный двор от регулярного парка. Главные видовые раскрытия и панорамы при всех трансформациях в усадьбе и в парке, в том числе после последней «реставрации», пока ещё воспринимаются как исторические;

11) в целом в Михалкове сохранилось многообразие видовых раскрытий и панорам как характерная особенность ландшафта данного пейзажного парка, включающего ядро усадьбы с выразительными объёмными сооружениями парадного двора и его раскрытием на композицию регулярного парка.

\section{Последствия просчётов в методологии}

Как мы уже говорили, особенности регулярного парка сегодня изучены несколько лучше, чем пейзажного в связи реставрационными работами разных лет. Пейзажная часть парка периода создания усадьбы мало изучена и практически не описана. В обоснованиях научной реставрации не уделялось достаточного внимания исследованию ландшафтных особенностей пейзажного парка.

В результате главные особенности усадьбы Михалково как произведения садово-паркового искусства, определяющие её принадлежность пейзажному стилю и заключающиеся в ведущей композиционной роли частично преобразованного естественного ландшафта, недостаточно изучены. Не получили должной оценки трансформации гидрологической системы парка. Определяющая композиционная роль пейзажного парка, его ландшафтной системы в ансамбле проигнорирована не только в «Паспорте памятника садово-паркового искусства», но и в последующих научно-реставрационных исследованиях и проектах. 
В «Концепции реставрации и приспособления к современному использованию объекта культурного наследия регионального значения (произведения садово-паркового искусства) “Усадьба Михалково"», разработанной НИИПИ Генплана г. Москвы, в 2012-2014 годах, территории, прилегающие к Большому Головинскому пруду, условно разбиты на несколько «зон благоустройства» советского периода.

В дальнейшем в научно-реставрационных исследованиях, выполненных для проекта реставрации в 2017 году (000 «Достояние»), также игнорировались стилистические особенности, характерные для пейзажных парков конца XVIII века. Не была обоснована композиционная роль ядра усадьбы и составных его элементов - архитектурного ансамбля парадного двора и регулярного парка. Пейзажного парка вроде бы вовсе не существует, роли исторического ландшафта, рельефа и гидрологии не раскрыты. Не описаны характерный породный состав насаждений, особенности луговых фитоценозов и цветников. Не рассмотрены утраченные видовые ракрытия и панорамы,возможности их восстановления.

Таким образом, проблема сохранения целостного произведения садово-паркового искусства конца XVIII века, выполненного в стилистике пейзажного парка, авторами работы не была проанализирована. А в качестве главной задачи прозвучало «приспособление к современному использованию». Не будем забывать, что достаточно долго существовала идея установки ограждения по границам территории с федеральным статусом - ядра усадьбы. Сохранение остального, видимо, интересовало меньше. Впоследствии это обстоятельство негативно повлияло на проект второй очереди реставрации парка - основной части, прилегающей к Головинским прудам.

Просчёты в подходе (методологии) привели к тому, что проведённые масштабные и дорогостоящие работы по благоустройству основной части парка Михалкова оказались недостаточно научно-обоснованными и проводились с многочисленными нарушениями требований к сохранению объекта культурного

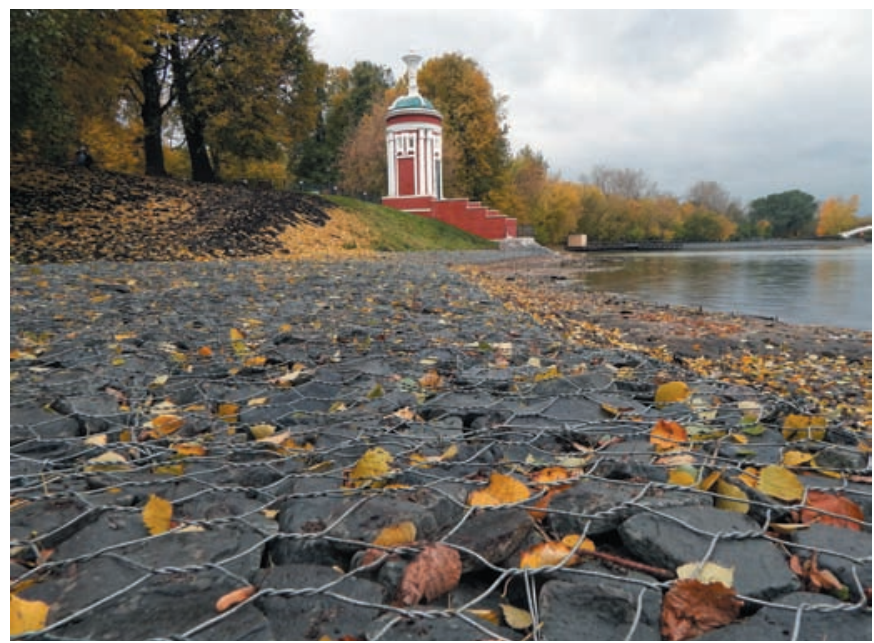

a)

Рис. 2. «Берегоукрепление» прудов парка Михалково в 2017 году: а) берега Большого Головинского пруда в районе беседкиротонды; б) берега копаных прудов в регулярном парке наследия, вызвали многочисленные протесты жителей и общественности. Остались совершенно неизученными изменения береговой линии, характера ландшафта, особенностей ландшафтных поверхностей. Без всяких обоснований берега Головинских и копаных прудов изрыли и обложили «габионами» (рис. 2), провели необоснованную вырубку насаждений, устроили пляж, за счёт озеленённых территорий увеличили плотность дорожно-тропиночной сети, площадь твёрдых покрытий, устроили велодорожки, что недопустимо в историческом парке [11; 12].

С нашей точки зрения, в дальнейшем при проектировании реставрации парка усадьбы Михалково и других аналогичных парков конца XVIII века необходимо руководствоваться требованиями реставрации и консервации пейзажного стиля Необходимо уделять внимание вопросам географического исследования ландшафта, ландшафтно-историческому анализу, современной ландшафтной организации и объёмно-пространственным характеристикам насаждений. Многое из описания аутентичных методов и приёмов создания пейзажных парков конца XVIII столетия можно почерпнуть в работах Болотова [8; 9], в которых детально описаны как принципы, так и материалы и технологии работ этого периода.

Проектируя приспособление исторического парка пейзажного стиля к современному использованию, не следует нарушать целостности его архитектурно-пространственной композиции. Она должна сохраняться, консервироваться и реставрироваться на основе использования аутентичных принципов организации ландшафта, элементов озеленения, устройства дорожно-тропиночной сети, использования исторически оправданных малых архитектурных форм, освещения и цветочного оформления. Допустимость проектных предложений каждый раз должна быть проверена методами визуально-ландшафтного анализа.

Исторически оправданными приёмами и методами благоустройства, озеленения и цветочного оформления можно было акцентировать отдельные ландшафтные участки пейзажного

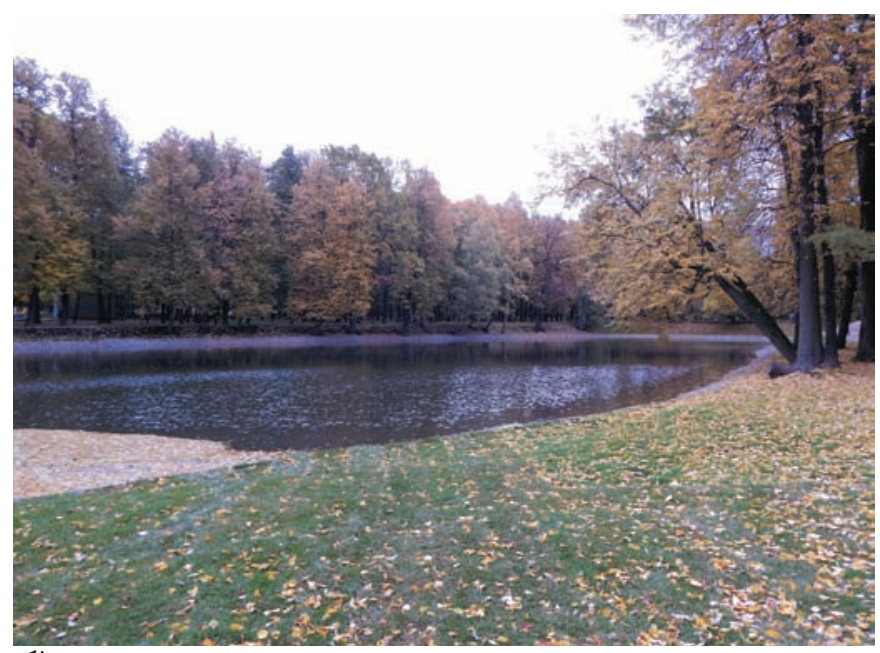

б)

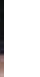


парка, расположенные в наиболее интересных местах в непосредственном окружении архитектурного ансамбля, в прибрежной зоне, в зоне дубовой рощи. Однако следовало делать это продуманно, чтобы сохранить облик и атмосферу «исторического парка». Получилось другое - парк культуры и отдыха советского периода.

При планировании и проведении реставрационных работ необходимо в парке усадьбы Михалково обеспечить максимальное сохранение доли озеленения, береговой линии, рельефа.

В последующих реставрациях в целях сохранения восприятия парка, необходимо исключить необоснованное повышение плотности дорожно-тропиночной сети в прогулочных зонах, сохранить основные панорамы и виды, не искажая их установкой неоправданных объектов (МАФ), использовать исторически обусловленный ассортимент насаждений и цветочного оформления.

$$
* * *
$$

Рассмотренные проблемы реставрации пейзажного парка усадьбы Михалково, которые должным образом не были решены в рамках работ 2016-2017 годов, когда их авторы недостаточно внимания уделили вопросам сохранения памятника, но чрезмерно много внимания - вопросам «современного использования», предстоит решить в будущих научно-реставрационных исследованиях и проектах. В Михалкове необходима реставрация, основанная на принципах создания пейзажных парков соответствующего периода. Если уникальными особенностями пейзажного парка системно не заниматься, то памятник садово-паркового искусства конца XVIII века, где авторство принадлежит В.И. Баженову, вскоре может быть утрачен и превратится в рядовой «объект благоустройства». К сожалению, эта тенденция уже задана последней «парковой реставрацией». Анализ опыта работ позволяет нам сделать следующие научные и практические выводы:

1. Анализ истории создания и особенностей парка усадьбы Михалково, расположенной на севере современной Москвы, показывает, что рассматриваемый объект культурного наследия регионального значения, представляет собой выдающееся произведение садово-паркового искусства конца XVIII века, выполненное в соответствии со стилистическими особенностями устройства пейзажных парков («натуральных садов») этого периода и указывает на принадлежность (или близость) к творчеству В.И. Баженова.

2. Особенности парка усадьбы Михалково недостаточно изучены, а утверждённый предмет охраны данного объекта культурного наследия требует существенной доработки, особенно в части рельефа, ландшафтных, гидрологических и гидрогеологических факторов.

3. Рекомендуется провести дополнительные историкокультурные исследования и уточнить «предмет охраны» произведения садово-паркового искусства пейзажного стиля этого периода, который включал парадный двор, обращённый в сохраняемый регулярный парк с копаными прудами и об- ширную территорию частично преобразованного естественного ландшафта с Головинскими прудами, с некогда свободной планировкой, акцентированной беседками-ротондами и ценными насаждениями, с замечательными панорамными и видовыми раскрытиями ансамбля.

4. Перспективы сохранения «Усадьбы Михалково»как объекта культурного наследия регионального значения связаны с выводом (перепрофилированием) сторонних пользователей, межеванием территории и с проведением кадастровых работ, с корректировкой и переутверждением границ памятника, режимов использования территории и уточнением «предмета охраны» с учетом особенностей архитектурно-пространственной и ландшафтной организации пейзажных парков конца восемнадцатого века.

\section{Лumepamypa}

1. Горохов, В.А. Зелёная природа города. Садово-парковое искусство России : в 2 томах. / В.А. Горохов.- М. : Архитектура-С, 2013. - 592 с.

2. Щукина, Е.П. Подмосковные усадебные сады и парки конца XVIII века / Е.П. Щукина. - М. : Институт наследия, 2007. - 383 с.

3. Нащокина, М.В. Русские сады. XVIII - первая половина XIX века / М.В. Нащокина. - М. : Арт-Родник, 2007. - 256 с.

4. Ожегова, Е.С. Ландшафтная архитектура. История стилей / Е.С. Ожегова; под ред. Д.О. Швидковского. - М. : Оникс : Мир и Образование, 2009. - 559 с.

5. Сокольская, О.Б. История садово-паркового искусства : Учебное пособие для студентов вузов / О.Б. Сокольская. - М. : ИНФРА-М, 2004. - 348 с.

6. Щукина, Е.П. Методика восстановления садов и парков XVIII-XIX веков / Е.П. Щукина // Теория и практика реставрационных работ. - 1973. - № 3. - С. 30-34.

7. Ильинская, Н.А. Восстановление исторических объектов ландшафтной архитектуры / Н.А. Ильинская. - Л. : Стройиздат : Ленингр. отделение, 1984. - 145 с.

8. Болотов, А.Т. Практические замечания о превращении простых натуральных лесочков в увеселительные / А.Т. Болотов // Экономический магазин. - 1784. - Ч. 20.

9. Болотов, А.Т. 0 направлении старых садов / А.Т. Болотов // Экономический магазин. - 1784. - Ч. 12.

10. С. Романюк. По землям московских сёл и слобод. Ч.2. - М., 1999.

11. Беляева Е.Л. Опыт работ по сохранению и приспособлению к современному использованию части парка усадьбы «Михалково» / Е.Л. Беляева, С.А. Минкин // Градостроительство. - 2019. - № 3-4. - С. 83-93.

12. Беляева Е.Л. «Сохранение» и «обеспечение сохранности» при проектировании благоустройства и озеленения центров исторических городов / Е.Л. Беляева // Биосферная совместимость: человек, регион, технологии. - 2019. - № 3 (27). - С. 54-70.

13. Греч А.Н. Венок усадьбам [Текст] / А.Н. Греч. - М. : АСТ-Пресс, 2010. - 333 с., ил. ISBN 978-5-462-01008-8. 


\section{References}

1.Gorokhov V.A. Zelenaya priroda goroda. Sadovo-parkovoe iskusstvo Rossii [The green nature of the city. Gardening art of Russia] : v 2 tomakh. Moscow, Arkhitektura-S Publ., 2013, 592 p.

2. Shchukina E.P. Podmoskovnye usadebnye sady i parki kontsa XVIII veka [Manor gardens and parks near Moscow at the end of the 18th century]. Moscow, Heritage Institute Publ., 2007, 383 p.

3. Nashchokina M.V. Russkie sady. XVIII - pervaya polovina XIX veka [Russian gardens. XVIII - the first half of the XIX century]. Moscow, Art-Rodnik Publ., 2007, 256 p.

4. Ozhegova E.S. Landshaftnaya arkhitektura. Istoriya stilei [Landscape architecture. History of styles], D.0. Shvidkovskii (ed.). Moscow, Oniks : Mir i Obrazovanie Publ., 2009, 559 p.

5. Sokol'skaya 0.B. Istoriya sadovo-parkovogo iskusstva : Uchebnoe posobie dlya studentov vuzov [History oflandscape gardening art. A textbook for university students]. Moscow, INFRA-M Publ., 2004, 348 p.

6. Shchukina E.P. Metodika vosstanovleniya sadov i parkov XVIII-XIX vekov [Methodology for the restoration of gardens and parks of the XVIII - XIX centuries]. Teoriya i praktika restavratsionnykh rabot [Theory and practice of restoration work], 1973, no. 3, pp. 30-34.

7. Il'inskaya N.A. Vosstanovlenie istoricheskikh ob"ektov landshaftnoi arkhitektury [Restoration of historical objects of landscape architecture]. Leningrad, Stroiizdat Publ., 1984, 145 p.
8. Bolotov A.T. Prakticheskie zamechaniya o prevrashchenii prostykh natural'nykh lesochkov $v$ uveselitel'nye [Practical notes on the transformation of simple natural forests into amusement]. Ekonomicheskii magazin, 1784, part 20.

9. Bolotov A.T. 0 napravlenii starykh sadov [About the direction of old gardens]. Ekonomicheskii magazine, 1784, part 12.

10. S. Romanyuk. Po zemlyam moskovskikh sel i slobod. [0n the lands of Moscow villages and settlements], Part 2. Moscow, 1999.

11. Belyaeva E.L., Minkin S.A. Opyt rabot po sokhraneniyu i prisposobleniyu k sovremennomu ispol'zovaniyu chasti parka usad'by «Mikhalkovo» [Experience in preserving and adapting to modern use part of the park of the Mikhalkovo estate.]. Gradostroitel'stvo [Urban Planning], 2019, no. 3-4, pp. 83-93.

12. Belyaeva E.L. «Sokhranenie» $i$ «obespechenie sokhrannosti» pri proektirovanii blagoustroistva i ozeleneniya tsentrov istoricheskikh gorodov ["Preservation" and "preservation" in the design of landscaping and landscaping of the centers of historical cities.]. Biosfernaya sovmestimost': chelovek, region, tekhnologii [Biosphere Compatibility: Human, Region, Technology], 2019, no. 3 (27), pp. 54-70.

13. Grech A.N. Venok usad'bam [A wreath at the estates]. Moscow, AST-Press Publ., 2010, 333 p., Ill. ISBN 978-5-46201008-8.

Беляева Елена Львовна (Москва). Кандидат технических наук, советник РААСН, член-корреспондент РАЕН. Директор 000 «Институт геобиосферных исследований» (113105, Москва, Варшавское шоссе, 8. 000 «ИГБИ»). Эл.почта: igbi@уandex.ru.

Маркина Ирина Александровна (Москва). Ландшафтный архитектор.

Могинов Борис Григорьевич (Москва). Архитектор-реставратор.

Belyaeva, Elena L. (Moscow). Candidate of Technical Sciences, Advisor to RAACS, Corresponding Member of the Russian Academy of Natural Sciences. Director of the 000 "Institute of Geobiosphere Research" (8 Varshavskoye Shosse, Moscow, 113105.000 "IGBI").E-mail: igbi@yandex.ru.

Markina, Irina A. (Moscow). Landscape architect.

Moginov, Boris G. (Moscow). Architect Restorer 